\title{
Estimation of Fluoride in Different Types of Commercially Available Wine
}

\section{Lalitha Rani Chellappa', Pradeep Kumar Rathinavelu², Meignana Arumugham Indiran²,} Srisakthi Doraikanan ${ }^{4}$ and Jayashri . $P^{5}$

${ }^{1}$ Post graduate student Department of Public Health Dentistry, Saveetha Dental college,

Saveetha Institute of Management and Technical Sciences, Saveetha University, No.162,

Poonamallee high road, Chennai 600077, Tamil Nadu, India

${ }^{2}$ Professor Department of Public Health Dentistry, Saveetha Dental college, Saveetha Institute

of Management and Technical Sciences, Saveetha University, No.162, Poonamallee high road,

Chennai 600077, Tamil Nadu, India

${ }^{3}$ Professor and Head Department of Public Health Dentistry, Saveetha Dental college, Saveetha

Institute of Management and Technical Sciences, Saveetha University,No.162, Poonamallee

high road, Chennai 600077, Tamil Nadu, India

${ }^{4}$ Reader Department of Public Health Dentistry, Saveetha Dental college, Saveetha Institute of

Management and Technical Sciences, Saveetha University, No.162, Poonamallee high road,

Chennai 600077, Tamil Nadu, India

${ }^{5}$ Senior Lecturer Department of Public Health Dentistry, Saveetha Dental college, Saveetha Institute

of Management and Technical Sciences, Saveetha University, No.162, Poonamallee high road,

Chennai 600077, Tamil Nadu, India

\section{ABSTRACT}

Winemaking or wineification is the production of wine, starting with the selection of the fruit, its fermentation into alcohol, and the bottling of the finished liquid. The history of wine-making stretches over millennia. Studies have shown that In terms of types of alcoholic drinks, the highest fluoride levels were determined in beers and wines, while the lowest levels were observed in vodkas. These data confirm the fact that alcoholic beverages need to be considered as a significant source of fluoride delivered into the body.The aim of the study is to estimate the amount of fluoride in different types of commercially available wine in India. Seven samples were collected from various sources in Chennai. The samples are Shiraz red wine, Merlot red wine, Chenin white wine, Chardonnay sauvignon blanc white wine, Rose wine, Sparkling wine and Fortified wine. The samples were collected using sterile containers in Chennai. Each sample was collected around $100 \mathrm{ml}$. and the fluoride testing was done by SPADNS APHA 23rd edition 2017 -4500 FBD. Only the two samples of red wine had $0.4 \mathrm{mg} / \mathrm{L}$ and $0.2 \mathrm{mg} / \mathrm{L}$ respectively and others had below detection level of fluoride where detection level is $0.1 \mathrm{mg} / \mathrm{L}$.The present study shows that there is permissive amount of fluoride in some type and brands of wines commercially available in India. Even though it is in permissive amounts, and can be used as anti-cariogenic it can cause erosion if used excessively. Therefore wine drinking should be reduced or kept in minimal amounts.

KEY WORDS: WINE, FLUORIDE CONCENTRATION, WINERY, FLUOROSIS, OSTEITIS DEFORMANS, ALCOHOLIC DRINKS.

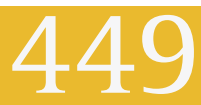




\section{ARTICLE INFORMATION}

${ }^{*}$ Corresponding Author: pradeepkumarr.sdc@saveetha.com Received 1st Aug 2020 Accepted after revision 15th Sep 2020

Print ISSN: 0974-6455 Online ISSN: 2321-4007 CODEN: BBRCBA

Thomson Reuters ISI Web of Science Clarivate Analytics USA and Crossref Indexed Journal

\section{Clarivate
Analytics}

\section{Crossef}

NAAS Journal Score 2020 (4.31) SJIF: 2020 (7.728)

A Society of Science and Nature Publication,

Bhopal India 2020. All rights reserved.

Online Contents Available at: http//www.bbrc.in/

Doi: http://dx.doi.org/10.21786/bbrc/13.8/179

\section{INTRODUCTION}

It is surprising that the wine industry attracts so much attention, given its relative size. Vines cover less than $0.5 \%$ of the world's crop land and wine accounts for just $0.4 \%$ of global household consumption - but for millions of investors and hundreds of millions of consumers, the industry's products command intense interest, often bordering on obsession(Anderson, 2004) Wine is a unique commodity. Its production predates recorded history, as does the discovery of the healthful benefits of wine, now largely attributed to the antimicrobial activity of ethanol('A History of Wine as Therapy', 1964).

Throughout antiquity the conversion of grapes into wine was considered a gift from the gods and the best wines were thus reserved for the elite of society. The image of wine as a beverage of the affluent persists even today. Wine was also one of the first commodities to be bartered by early civilizations engaged in international trade. Then, as now, the most successful wine producers were those who grasped market forces of supply and demand, and whose products met the prevailing definition of quality. Today, wine is an integral component of the culture of many countries, a form of entertainment in others, and a libation of choice for advocates of its health benefits. Unlike many modern foods, wine's attractions rely not on bold consistent flavours, but upon a subtle array of shifting sensations that make its charm difficult to define. In essence, wine producers are selling a sensory experience to the consumer. Wine consumers in developed nations are typically prosperous, but wine is also consumed in impoverished areas where it is still safer to drink than the local water supply.

Regardless of the region in which the wine is produced or the economic status of the consumer, all wines are expected to be pleasant experiences for the imbiber. In past generations, the definition of quality was the preserve of the wine producer, and consumers who did not like a particular style of wine were often made to feel uncultured. But globalization and the accompanying rapid worldwide access to information has resulted in a more knowledgeable and empowered consumer with a more sophisticated understanding of product value and a discriminating demand for quality. The control of the definition of quality has thus shifted to the consumer. Success as a wine producer in the twenty-first century requires a thorough appreciation of human behaviour and product choice.

Whatever the explanation, the wine industry has come to realise that centre stage is a market-driven space and today's consumers vote with their wallets for those wine producers who offer a pleasurable and recognisable 'sensory experience'. They expect a safe product produced in an environmentally sustainable manner and enjoyable in all sensory aspects(Bisson et al., 2002). The terms quality and value are widely used in reference to wine; the International Standards Organisation defines quality as the "degree to which a set of inherent characteristics fulfils requirements(Reynolds, 2010)

It is instructive to relate this definition to the different elements involved in the wine production chain. To the consumer who compares wines for purchase, fulfilling requirements is associated with the 'intrinsic' sensory quality of the wine, i.e. how the wine pleasures on appearance, the nose and the palate, as well as the perceived value(König, Unden and Fröhlich, 2009). Value is related to both intrinsic quality and image - the latter derived from many aspects such as how the wine is marketed, awards received, winery environmental sustainability record - and cost (Francis et al. 2005). Thus, a wine with delightful and recognisable sensory attributes and a high perceived image at a competitive price would be considered by consumers as high in value.

As far as consumers are concerned, the aroma and flavour of wine are among the primary characteristics that determine its quality and value(Swiegers et al., 2005). The aroma of wines is a unique mixture of volatile compounds originated from grape fruits (varietal aromas), secondary products formed during the wine fermentation (fermentative aromas) and ageing (post-fermentative aromas(Swiegers et al., 2005).The nature and amount of the synthesised volatile compounds depend on multiple factors, such as the nitrogen content of the must, the temperature of fermentation and the yeast strain(Molina et al., 2007; Hui and Özgül Evranuz, 2012)

These issues are complex, requiring producers to understand the latest developments in wide-ranging disciplines of science and technology. The present-day wine industry is focused on optimizing the attractiveness of the product . In the future, the industry will need to go beyond this, paying more attention to the extrinsic factors motivating product choice, while ensuring that production remains cost-effective and economically sound(Bisson et al., 2002). Fluorine is the third most abundant on earth. It cannot exist outside a controlled environment without combining with other compounds to form fluorides (Chouhan and Flora, 2010). Main source of fluoride in ground water is fluoride bearing rocks from which it gets leached out into the water. 
Fluorides can occur in 3 forms namely calcium fluoride or fluorspar, apatite or rock phosphate and cryolite(Bhattacharya et al., 2008) It is harmful when it exceeds the permissible limit of $1.2 \mathrm{mg} \mathrm{l}-1$ in water('International Standards for Drinking Water (3rd Edition): Pp. 70. Geneva, World HealthOrganization, 1971.90p', 1973). Low concentration of fluoride below $0.5 \mathrm{ppm}$ causes dental caries(Clark, 1993; Acharya et al., 2008). Smaller quantities (<1.0 mg l-1) in drinking water are usually considered good to have a beneficial effect on the rate of occurrence of dental caries, particularly among children(World Health Organization, 1993; National Research Council et al., 2007; Gupta and Ayoob, 2016). While high concentrations above $1.5 \mathrm{mg} \mathrm{l-1}$ may cause an endemic disease called dental fluorosis, intake of F- concentrations above $3.0 \mathrm{mg} \mathrm{l-1}$ may cause skeletal fluorosis (Singaraja et al., 2014) On the contrary, change in water fluoridation policy to $0.5 \mathrm{ppm}$ along with fluoridated toothpaste has resulted in a decrease in fluorosis without compromising the caries preventive effect(Nor et al., 2018).

Excess fluoride in wine is common in abroad and are potential to cause a new disease called periostitis deformans(Chitkara, Rackoff and Beltran, 2014) India is one of the 22 countries prone to fluorosis in the world. Dental fluorosis is a major endemic in 14 states and 150000 villages in India such as in Andhra Pradesh, Bihar, Gujarat, Madhya Pradesh, Punjab, Rajasthan, Tamil $\mathrm{Nadu}$ and Uttar Pradesh in India 62 million population are at risk of developing fluorosis by drinking high fluoride water. Fluoride in groundwater has been reported in various places across India especially in Andhra Pradesh, Chhattisgarh(Reddy et al., 2010; Dashavantha Reddy, Venkateswara Rao and Kancha, 2017) Studies have reported fluoride concentration in Andhra Pradesh and Tamil Nadu. In Tamil Nadu, fluorosis is reported to be in the districts of Dharmapuri, Erode, Salem, Coimbatore, Madurai, Vellore and Virudhunagar(Rao and Subba Rao, 2003; Kumar and John, 2011; kumar.R et al., 2014; Kumar and Preethi, 2017; Kumar, Pradeep Kumar and Vijayalakshmi, 2017; Maheswari et al., 2017).

As we are already a fluorosis endemic country it is necessary to estimate the amount of fluoride available in wine in India. We have successfully completed numerous epidemiological studies for the betterment of our community(Prabakar, John and Srisakthi, 2016; Kannan et al., 2017; Kumar and Preethi, 2017; Kumar, Pradeep Kumar and Vijayalakshmi, 2017; Prabakar, John, I. Arumugham, et al., 2018; Prabakar, John, I. M. Arumugham, Kumar and Sakthi, 2018; Prabakar, John, I. M. Arumugham, Kumar and Srisakthi, 2018; Vishnu Prasad et al., 2018; Harini and Leelavathi, 2019; Khatri et al., 2019; Manchery et al., 2019; Mohapatra et al., 2019; Neralla et al., 2019; Pavithra, Preethi Pavithra and Jayashri, 2019; Pratha and Prabakar, 2019; Shenoy, Salam and Varghese, 2019; Mathew et al., 2020; Samuel, Acharya and Rao, 2020). So in this research, we are estimating the amount of fluoride in different types of commercially available wine in India

\section{MATERIAL AND METHODS}

This is a cross sectional study studying the fluoride content in the commercial wines available in India. In the present study we have collected 7 wine samples to test for fluoride content in the second week of October 2018.

\section{There are approximately 6 types of wine available with its own subtypes: \\ 1. Red wine \\ 2. White wine \\ 3. Rose wine \\ 4. Sparkling wine \\ 5. Fortified wine \\ 6. Dessert wine(The Australian \& New Zealand Wine Industry Journal, 2007)}

India has about 60 wineries and 123000 acres of land for vineyards. the most important companies of Indian vinery are chateau indage limited, grover vineyards and sula vineyards. As the dessert wine was only available in the northern part of India it was not included in the study. As red and white wine are the most consumed wine types, we have included two samples in each type of two different leading brands.

\section{Sample collection:}

1. Shiraz red wine

2. Merlot red wine

3. Chenin white wine

4. Chardonnay sauvignon blanc white wine

5. Rose wine

6. Sparkling wine

7. Fortified wine

The samples were collected using sterile containers in Chennai from three different places in the city. Each sample was collected around $100 \mathrm{ml}$. The samples were collected by cluster sampling technique.

Fluoride testing method: The samples are tested for fluoride by APHA 23rd edition 2017 -4500 FBD. It is done by SPADNS method . It is a colorimetric method and based on the reaction between fluoride and a zirconium dye lake. Fluoride reacts with the dye lake and leaves a portion of it into a colourless complex anion (ZrF62- ) and the dye. As the amount of fluoride increases, the colour produced becomes progressively lighter. SPADNS solution used is sodium 2 (parasulfopenylazo)-1,8 dihydroxy -3,6 naphthalene disulfonate, zirconyl acid reagent prepared by adding $\mathrm{HCl}$ and Acid zirconyl SPADNS reagent prepared by mixing equal volumes of SPADNS solution and zirconyl acid reagent. There is a reference solution prepared by adding $10 \mathrm{ml}$ of SPADNS solution to $100 \mathrm{ml}$ distilled water. Dilute $7 \mathrm{ml}$ of con $\mathrm{HCl}$ to $10 \mathrm{ml}$ and add to diluted SPDNS solution. The procedure is done and colour development is measured by spectrophotometer to estimate the fluoride concentration. 


\section{RESULTS AND DISCUSSION}

Out of 7 samples, only the two red wines showed detectable levels of fluoride but that was in a safe range. The Shiraz brand showed $0.4 \mathrm{mg} / \mathrm{L}$ and Merlot brand showed $0.20 \mathrm{mg} / \mathrm{L}$ fluoride concentration(table 1). The white wine, rose wine, sparkling wine and fortified wine are showing less than $0.1 \mathrm{mg} / \mathrm{L}$ of fluoride concentration. The Indian wine industry has been steadily developing over the last ten years. Wine is gradually becoming a part of urban Indian lifestyle. Domestic wine consumption touched more than 10 million litres in 2007, and may go up to 15 million litres for the current year, from a mere 1 million litres in 2001. Nearly 80\% of the demand for wine centres in the following major cities of the country - New Delhi, Mumbai, Chennai, Kolkata, Pune and Bangalore. The consumption pattern is as follows: Mumbai (39\%), Delhi (23\%), Bangalore (9\%) Goa (9\%), whereas the rest of India has only $20 \%$ consumption. The overall consumption of wines in India is approximately 400,000 cases a year of which 85 percent are table wines and the remaining are the expensive varieties. Out of the 400,000 cases, about 50,000 cases are imported from various sources. Today, the consumption per head is roughly 0.0030 litre per annum(Rathore, 2006).

Fluoride is always known as a double edged sword because it has anti carious effects on teeth when consumed in normal range. While excess consumption leads to both skeletal and dental fluorosis. A new emphasis describes fluoride exposures as being either pre eruptive and post eruptive fluorosis. Post eruptive fluoride acts mainly by reducing demineralization and enhancing remineralization. Ingestion of fluoride before 3-4 years of age is critical to the possibility of fluorosis in the early erupting permanent dentition, including the maxillary incisors. Thus the damage is very often done before young patients have their first dental visit(Levy, 2003). Children who are exposed to excess fluorides from childhood show symptoms of fluorosis more than adults. Hence the fluoride problem in an area may not be decided on the fact that adults have good teeth with no discolouration.

Exposure to very high fluoride over a prolonged period of time results in acute to chronic skeletal fluorosis. Early stages start with pain in joints, muscle weakness, sporadic pain, chronic fatigue. which in later stages, calcification of bones happen, osteoporosis, and osteosclerosis in which bones become denser and develop abnormal structure. In advanced stages joints become completely weak and moving them becomes difficult. Unfortunately Skeletal fluorosis is usually identified in later stages only(Satpathy et al., 2014).National research council states that skeletal fluorosis might occur in people who have continuously ingested 10 to $20 \mathrm{mg}$ of fluoride per day for over 10-20 years Other effects include low $\mathrm{Hb}$ level, deformities in RBC, thirst, headache, skin rashes, nervousness, neurological manifestations, nausea, abdominal pain, still births, male sterility etc. Further some authorities have reported that it may be impossible to achieve fluoride based caries prevention without some degree of fluorosis(Meenakshi, Meenakshi and Maheshwari, 2006).

In a study done by Bruno E. Trombella et al, maxmimum fluoride concentration of the white wine was $2.3 \mathrm{mg} / \mathrm{L}$ and red wine was $3.0 \mathrm{mg} / \mathrm{L}$ (Trombella et al., 2003) .In the present study the maximum fluoride concentration is $0.4 \mathrm{mg} / \mathrm{L}$. In the present study, fluoride was present in permissive amount in red wines. Similar results have been obtained from studies done by Marta Goschorka et al the maximum fluoride concentration of wine was 0.1 mg/L(Goschorska et al., 2016),rees et al (Rees, Burford and Loyn, 1998)and the research on the concentration of fluoride in wines from canary islands(Martínez et al., 1998; Gómez et al., 2003). In the present study, maximum concentration of fluoride in white wines were below 0.1 $\mathrm{mg} / \mathrm{L}$ whereas in a study by Soraya Paz et al, 0.34 was the maximum concentration of fluoride in white wine and $0.1 \mathrm{mg} / \mathrm{L}$ was in red wine respectively(Paz et al., 2017)

It is noteworthy that more than $70 \%$ of the fluoride delivered into the body every day is contained in beverages, especially tea(Joshi et al., 2011). While anecdotal evidence exists regarding the problem of dental erosion in winemakers and others in the wine trade who are required to taste wines frequently, there has been negligible form documentation. One case of erosion in a winemaker has been reported, but the magnitude of the problem has not been established. Regular exposure to fruit juices or soft drinks is well recognized as a cause of erosion and it may be anticipated that wine will have a similar potential due to its acid content. In a study of erosion, using human enamel, it was found that exposure to a Swiss white wine, at $\mathrm{pH} 3.7$ for 20 minutes, resulted in a decrease of microhardness comparable to that caused by $50 \mathrm{mmol} / \mathrm{L}$ lactic acid(Lussi, Jäggi and Schärer, 1993).

The erosive capability of wine, as with other acidic drinks, will be determined by the individual $\mathrm{pH}$ value, titratable amount of base as well as the phosphate and fluoride content. The various wines made in different regions of the world have a range of acid contents and types as well as the amount of phosphate and fluoride present. Accordingly, there may be some variation in their potential to cause erosion although it most probably remains a feature with all wines. With the problem of dental erosion in winemakers apparently not being well documented, no appropriate management regimes have been widely established. Currently, there is no alternative to the grape juice and wine being tasted regularly throughout manufacture. The use of any alkaline mouth rinse after each tasting has the potential to alter taste acuity but it would seem useful to rinse with water on each occasion.

Topical fluoride rinses should have the ability to reduce enamel solubility and the use of a 0.05 per cent sodium fluoride rinse, at least daily, is advocated. Standard oral hygiene, using a fluoride dentifrice, is appropriate for these individuals but with advice not to brush excessively and to use a soft nylon toothbrush. In those cases where 
erosive lesions are already present, restoration may be required for aesthetic reasons as well as for sensitivity. Glass ionomers, composites, fixed prostheses and dentine bonding agents have been advocated (Gallien, Kaplan and Owens, 1994). The excessive ingestion of fluoride in foods and drinks leads, to erosion of the enamel has been reported in various studies(Gray, Ferguson and Wall, 1998; Mok, McIntyre and Hunt, 2001; Piekarz et al., 2008; Amaral, Vettore and Leão, 2009).

Table 1. Shows the distribution of concentration of fluoride in all the study samples. Only Shiraz red wine and Merlot red wine had detectable levels of fluoride concentration. The white wine, rose wine, sparkling wine and fortified wine are showing less than $0.1 \mathrm{mg} / \mathrm{L}$ of fluoride concentration.It shows that red wine contains more fluoride than the other types of wine. But the concentration of these did not exceed the permissive level of fluoride intake per day.

\begin{tabular}{|l|c|c|c|}
\hline S.No & Type of wine & F- concentration(mg/L) & Detectable Level \\
\hline 1 & Shiraz red wine & 0.40 & 0.1 \\
\hline 2 & Merlot red wine & 0.20 & 0.1 \\
\hline 3 & Chenin white wine & Below Detectable Level & 0.1 \\
\hline 4 & $\begin{array}{c}\text { Chardonnay sauvignon } \\
\text { blanc white wine }\end{array}$ & Below Detectable Level & 0.1 \\
\hline 5 & Rose wine & Below Detectable Level & 0.1 \\
\hline 6 & Sparkling wine & Below Detectable Level & 0.1 \\
\hline 7 & Fortified wine & Below Detectable Level & 0.1 \\
\hline
\end{tabular}

Limitation of the study: During the process of wine making, the ground water of that particular area is added to dilute and ferment the wine. This can be a major determinant in fluoride concentration in wines prepared from various parts of the country. Another limitation of the study is lesser number of samples.

\section{CONCLUSION}

The present study shows that there is a permissive amount of fluoride in some type and brands of wines commercially available in India. But these data, as well as several reports by other authors, confirm the fact that alcoholic beverages need to be considered as a significant source of fluoride delivered into the body. Even though it is in permissive amounts, and can be used as anticariogenic it can cause erosion if used excessively and wine drinking should be reduced or kept in minimal amounts. As wine production has evolved from a cottage industry to global networks of consumer-aware producers, so has science. The challenges to scientists are the same as those to producers: to meet the demands of an inquiring public on issues that require an international and multidisciplinary approach.

\section{ACKNOWLEDGEMENTS}

Acknowledge all the staff of the department

Conflict of Interest: Nil

\section{REFERENCES}

Acharya, G. D. et al. (2008) 'Chemical Properties of Groundwater in Bhiloda Taluka Region, North Gujarat, India', E-Journal of Chemistry, pp. 792-796. doi:

\section{$10.1155 / 2008 / 592827$.}

A History of Wine as Therapy' (1964) Archives of Internal Medicine, p. 175. doi: 10.1001/ archinte.1964.03860070221050.

Amaral, C. da S. F., Vettore, M. V. and Leão, A. (2009) 'The relationship of alcohol dependence and alcohol consumption with periodontitis: a systematic review', Journal of dentistry, 37(9), pp. 643-651. doi: 10.1016/j. jdent.2009.04.011.

Anderson, K. (2004) The World's Wine Markets: Globalization at Work. Edward Elgar Publishing. Available at: https://play.google.com/store/books/ details?id=PMKc8Ed8qoIC.

Bhattacharya, P. et al. (2008) Groundwater for Sustainable Development: Problems, Perspectives and Challenges. CRC Press. Available at: https://play.google. com/store/books/details?id=00IQn3ZgvTYC.

Bisson, L. F. et al. (2002) 'The present and future of the international wine industry', Nature, 418(6898), pp. 696-699. doi: 10.1038/nature01018.

Chitkara, M., Rackoff, P. J. and Beltran, L. S. (2014) 'Multiple painless masses: periostitis deformans secondary to fluoride intoxication', Skeletal Radiology, pp. 555-556. doi: 10.1007/s00256-013-1788-z.

Chouhan, S. and Flora, S. J. S. (2010) 'Arsenic and fluoride: two major groundwater pollutants', Indian journal of experimental biology, 48(7), pp. 666-678. Available at: https://www.ncbi.nlm.nih.gov/ pubmed/20929051.

Clark, D. C. (1993) 'Appropriate uses of fluorides for 
children: guidelines from the Canadian Workshop on the Evaluation of Current Recommendations Concerning Fluorides', CMAJ: Canadian Medical Association journal = journal de l'Association medicale canadienne, 149(12), pp. 1787-1793. Available at: https://www.ncbi.nlm.nih. gov/pubmed/8261348.

Dashavantha Reddy, V., Venkateswara Rao, K. and Kancha, R. K. (2017) Insights on Global Challenges and Opportunities for the Century Ahead. BS Publications. Available at: https://play.google.com/store/books/ details?id=0rwQygEACAAJ.

Gallien, G. S., Kaplan, I. and Owens, B. M. (1994) 'A review of noncarious dental cervical lesions', Compendium , 15(11), pp. 1366, 1368-72, 1374; quiz 1374. Available at: https://www.ncbi.nlm.nih.gov/ pubmed/7758024.

Gómez, M. R. et al. (2003) 'Fluoride levels in wines of the Canary Islands (Spain)', European Food Research and Technology, pp. 145-149. doi: 10.1007/s00217002-0622-y.

Goschorska, M. et al. (2016) 'Fluoride Content in Alcoholic Drinks', Biological trace element research, 171(2), pp. 468-471. doi: 10.1007/s12011-015-0519-9. Gray, A., Ferguson, M. M. and Wall, J. G. (1998) 'Wine tasting and dental erosion. Case report', Australian dental journal, 43(1), pp. 32-34. doi: 10.1111/j.18347819.1998.tb00149.x.

Gupta, A. K. and Ayoob, S. (2016) Fluoride in Drinking Water: Status, Issues, and Solutions. CRC Press. Available at: https://play.google.com/store/books/ details?id=gMX1CwAAQBAJ.

Harini, G. and Leelavathi, L. (2019) 'Nicotine Replacement Therapy for Smoking Cessation-An Overview', Indian Journal of Public Health Research \& Development, 10(11), p. 3588. doi: 10.5958/09765506.2019.04144.5.

Hui, Y. H. and Özgül Evranuz, E. (2012) Handbook of Fermented Food and Beverage Technology Two Volume Set. CRC Press. Available at: https://play.google.com/ store/books/details?id=LUJZDwAAQBAJ.

International Standards for Drinking Water (3rd Edition): Pp. 70. Geneva, World HealthOrganization, 1971.90p' (1973) Public health, 87(4), pp. 147-148. doi: 10.1016/ S0033-3506(73)80078-2.

Joshi, S. et al. (2011) 'Skeletal fluorosis due to excessive tea and toothpaste consumption', Osteoporosis International, pp. 2557-2560. doi: 10.1007/s00198-0101428-6.

Kannan, S. S. D. et al. (2017) 'AWARENESS AND ATTITUDE TOWARDS MASS DISASTER AND ITS MANAGEMENT AMONG HOUSE SURGEONS IN A DENTAL COLLEGE AND HOSPITAL IN CHENNAI, INDIA', in Disaster Management and Human Health Risk
V. DISASTER MANAGEMENT 2017, Southampton UK: WIT Press (WIT Transactions on The Built Environment), pp. 121-129. doi: 10.2495/DMAN170121.

Khatri, S. G. et al. (2019) 'Retention of moisture-tolerant fluoride-releasing sealant and amorphous calcium phosphate-containing sealant in 6-9-year-old children: A randomized controlled trial', Journal of the Indian Society of Pedodontics and Preventive Dentistry, 37(1), pp. 92-98. doi: 10.4103/JISPPD.JISPPD_173_18.

König, H., Unden, G. and Fröhlich, J. (2009) Biology of Microorganisms on Grapes, in Must and in Wine. Springer Science \& Business Media. Available at: https:// play.google.com/store/books/details?id=6CR1vQUMwsC.

Kumar, P. R. and John, J. (2011) 'Assessment of periodontal status among dental fluorosis subjects using community periodontal index of treatment needs', Indian journal of dental research: official publication of Indian Society for Dental Research, 22(2), pp. 248-251. doi: 10.4103/0970-9290.84297.

kumar.R, P. et al. (2014) 'Assessment of Fluoride Concentration in Groundwater in Kanchipuram, Tamil Nadu, India', IOSR Journal of Environmental Science, Toxicology and Food Technology, pp. 45-46. doi: 10.9790/2402-08624546.

Kumar, R. P., Pradeep Kumar, R. and Vijayalakshmi, B. (2017) 'Assessment of Fluoride Concentration in Ground Water in Madurai District, Tamil Nadu, India', Research Journal of Pharmacy and Technology, p. 309. doi: 10.5958/0974-360x.2017.00063.4.

Kumar, R. P. and Preethi, R. (2017) 'Assessment of Water Quality and Pollution of Porur, Chembarambakkam and Puzhal Lake', Journal of advanced pharmaceutical technology \&t research, 10(7), p. 2157. doi: 10.5958/0974360X.2017.00380.8.

Levy, S. M. (2003) 'An update on fluorides and fluorosis', Journal , 69(5), pp. 286-291. Available at: https://www. ncbi.nlm.nih.gov/pubmed/12734021.

Lussi, A., Jäggi, T. and Schärer, S. (1993) 'The influence of different factors on in vitro enamel erosion', Caries research, 27(5), pp. 387-393. doi: 10.1159/000261569. Maheswari, E. et al. (2017) 'Fluoride content in various sources of drinking water in Chennai', Journal of Advanced Pharmacy Education \& Research| Apr-Jun, 7(2). Available at: https://www.speronline.com/japer/ Articlefile/JAPER_48_2017.pdf.

Manchery, N. et al. (2019) 'Remineralization potential of dentifrice containing nanohydroxyapatite on artificial carious lesions of enamel: A comparative in vitro study', Dental research journal, 16(5), pp. 310-317. Available at: https://www.ncbi.nlm.nih.gov/pubmed/31543937. Martínez, O. B. et al. (1998) 'Concentrations of fluoride in wines from the Canary Islands', Food 
additives and contaminants, 15(8), pp. 893-897. doi: 10.1080/02652039809374726.

Mathew, M. G. et al. (2020) 'Evaluation of adhesion of Streptococcus mutans, plaque accumulation on zirconia and stainless steel crowns, and surrounding gingival inflammation in primary molars: randomized controlled trial', Clinical oral investigations. doi: 10.1007/s00784020-03204-9.

Meenakshi, Meenakshi and Maheshwari, R. C. (2006) 'Fluoride in drinking water and its removal', Journal of Hazardous Materials, pp. 456-463. doi: 10.1016/j. jhazmat.2006.02.024.

Mohapatra, S. et al. (2019) 'Assessment of Microhardness of Enamel Carious Like Lesions After Treatment with Nova Min, Bio Min and Remin Pro Containing Toothpastes: An in Vitro Study', Indian Journal of Public Health Research \& Development, p. 375. doi: 10.5958/0976-5506.2019.02832.8.

Mok, T. B., McIntyre, J. and Hunt, D. (2001) 'Dental Erosion: In Vitro Model of Wine Assessor's Erosion', Australian Dental Journal, pp. 263-268. doi: 10.1111/ j.1834-7819.2001.tb00290.x.

Molina, A. M. et al. (2007) 'Influence of wine fermentation temperature on the synthesis of yeast-derived volatile aroma compounds', Applied microbiology and biotechnology, 77(3), pp. 675-687. doi: 10.1007/s00253007-1194-3.

National Research Council et al. (2007) Fluoride in Drinking Water: A Scientific Review of EPA's Standards. National Academies Press. Available at: https://play. google.com/store/books/details?id=cDiJAIbMD_oC.

Neralla, M. et al. (2019) 'Role of nutrition in rehabilitation of patients following surgery for oral squamous cell carcinoma', International Journal of Research in Pharmaceutical Sciences, pp. 3197-3203. doi: 10.26452/ijrps.v10i4.1622.

Nor, A. M. et al. (2018) 'The impact of a reduction in fluoride concentration in the Malaysian water supply on the prevalence of fluorosis and dental caries', Community Dentistry and Oral Epidemiology, pp. 492-499. doi: 10.1111/cdoe.12407.

Pavithra, R. P., Preethi Pavithra, R. and Jayashri, P. (2019) 'Influence of Naturally Occurring Phytochemicals on Oral Health', Research Journal of Pharmacy and Technology, p. 3979. doi: 10.5958/0974-360x.2019.00685.1.

Paz, S. et al. (2017) 'Determination of Fluoride in Organic and Non-organic Wines', Biological trace element research, 178(1), pp. 153-159. doi: 10.1007/s12011-0160910-1.

Piekarz, C. et al. (2008) 'An in vitro assessment of the role of Tooth Mousse in preventing wine erosion', Australian Dental Journal, pp. 22-25. doi: 10.1111/ j.1834-7819.2007.00003.x.
Prabakar, J., John, J., Arumugham, I. M., Kumar, R. P. and Srisakthi, D. (2018) 'Comparative Evaluation of Retention, Cariostatic Effect and Discoloration of Conventional and Hydrophilic Sealants - A Single Blinded Randomized Split Mouth Clinical Trial', Contemporary clinical dentistry, 9(Suppl 2), pp. S233S239. doi: 10.4103/ccd.ccd_132_18.

Prabakar, J., John, J., Arumugham, I. M., Kumar, R. P. and Sakthi, D. S. (2018) 'Comparative Evaluation of the Viscosity and Length of Resin Tags of Conventional and Hydrophilic Pit and Fissure Sealants on Permanent Molars: An In vitro Study', Contemporary clinical dentistry, 9(3), pp. 388-394. doi: 10.4103/ccd. ccd_131_18.

Prabakar, J., John, J., Arumugham, I., et al. (2018) 'Comparing the effectiveness of probiotic, green tea, and chlorhexidine- and fluoride-containing dentifrices on oral microbial flora: A double-blind, randomized clinical trial', Contemporary Clinical Dentistry, p. 560. doi: 10.4103/ccd.ccd_659_18.

Prabakar, J., John, J. and Srisakthi, D. (2016) 'Prevalence of dental caries and treatment needs among school going children of Chandigarh', Indian journal of dental research: official publication of Indian Society for Dental Research, 27(5), pp. 547-552. doi: 10.4103/09709290.195683.

Pratha, A. A. and Prabakar, J. (2019) 'Comparing the effect of Carbonated and energy drinks on salivary $\mathrm{pH}-$ In Vivo Randomized Controlled Trial', Research Journal of Pharmacy and Technology. A \& V Publications, 12(10), pp. 4699-4702. Available at: http://www. indianjournals.com/ijor.aspx?target=ijor:rjpt\&tvolume $=12$ ctissue $=10$ ctarticle $=019$.

Rao, N. S. and Subba Rao, N. (2003) 'Groundwater quality: focus on fluoride concentration in rural parts of Guntur district, Andhra Pradesh, India', Hydrological Sciences Journal, pp. 835-847. doi: 10.1623/hysj.48.5.835.51449.

Rathore, A. S. (2006) The Complete Indian Wine Guide: An Illustrated Companion to All Domestic Indian Wines and All Major International Wines in the Indian Market. Lotus Collection. Available at: https://play.google.com/ store/books/details?id=GR9HAAAAYAAJ.

Reddy, D. V. et al. (2010) 'Fluoride dynamics in the granitic aquifer of the Wailapally watershed, Nalgonda District, India', Chemical Geology, pp. 278-289. doi: 10.1016/j.chemgeo.2009.10.003.

Rees, J. S., Burford, K. and Loyn, T. (1998) 'The erosive potential of the alcoholic lemonade Hooch', The European journal of prosthodontics and restorative dentistry, 6(4), pp. 161-164. Available at: https://www. ncbi.nlm.nih.gov/pubmed/10596617.

Reynolds, A. G. (2010) Managing Wine Quality: Viticulture 
and Wine Quality. Elsevier. Available at: https://play. google.com/store/books/details?id=wIdwAgAAQBAJ.

Samuel, S. R., Acharya, S. and Rao, J. C. (2020) 'School Interventions-based Prevention of Early-Childhood Caries among 3-5-year-old children from very low socioeconomic status: Two-year randomized trial', Journal of public health dentistry, 80(1), pp. 51-60. doi: 10.1111/jphd.12348.

Satpathy, K. K. et al. (2014) 'Fluoride in ground water: a comment on "Fluorine contamination in ground water: a major challenge" published in Environmental Monitoring and Assessment, (2011) 173, 955-968', Environmental monitoring and assessment, pp. 21592163. doi: 10.1007/s10661-013-3525-4.

Shenoy, R. P., Salam, T. A. A. and Varghese, S. (2019) 'Prevalence and Clinical Parameters of Cervical Abrasion as a Function of Population, Age, Gender, and Toothbrushing Habits: A Systematic Review', World Journal of Dentistry, pp. 470-480. doi: 10.5005/ jp-journals-10015-1685.

Singaraja, C. et al. (2014) 'Geochemical evaluation of fluoride contamination of groundwater in the Thoothukudi District of Tamilnadu, India', Applied Water Science, pp. 241-250. doi: 10.1007/s13201-0140157-y.
Swiegers, J. H. et al. (2005) 'Yeast and bacterial modulation of wine aroma and flavour', Australian Journal of Grape and Wine Research, pp. 139-173. doi: 10.1111/j.1755-0238.2005.tb00285.x.

The Australian \& New Zealand Wine Industry Journal (2007). Australian Industrial Publishers. Available at: https://play.google.com/store/books/details?id=JhJAAAAYAAJ.

Trombella, B. E. et al. (2003) 'Determination of fluoride in wine by fluoride selective ion electrode, standard addition method: collaborative study', Journal of AOAC International, 86(6), pp. 1203-1207. Available at: https://www.ncbi.nlm.nih.gov/pubmed/14979703.

Vishnu Prasad, S. et al. (2018) 'Report on oral health status and treatment needs of 5-15 years old children with sensory deficits in Chennai, India', Special care in dentistry: official publication of the American Association of Hospital Dentists, the Academy of Dentistry for the Handicapped, and the American Society for Geriatric Dentistry, 38(1), pp. 58-59. doi: 10.1111/scd.12267.

World Health Organization (1993) Guidelines for Drinking-water Quality. World Health Organization. Available at: https://play.google.com/store/books/ details?id=kjizDwAAQBAJ. 